\title{
Progress in Achieving Sustainable Industrial Development - the Case of the Czech Republic and Poland ${ }^{1}$
}

\author{
Marta Ulbrych \\ Ph.D., Department of International Economics, College of Economics \\ Finance and Law, Cracow University of Economics, Cracow, Poland \\ e-mail: e-mail: ulbrychm@uek.krakow.pl
}

\begin{abstract}
The aim of this paper is to clarify the concept of sustainable industrial development and present the results of a study on the progress in achieving goals in this field adopted by the United Nations (UN) in 2015. The research covered the Czech and Polish economies in the period 2000-2018. Under the United Nations 2030 Agenda for Sustainable Development, the need to promote inclusive and sustainable industrialisation was identified. In the context of sustainable industrial development, it is emphasised that it should encourage a competitive economy, create employment, and protect the environment by efficiently utilising non-renewable resources. To assess this phenomenon in the analysed economies, indicators identified by the UN under SDG9 were used.
\end{abstract}

Keywords: green industrial policy, sustainable development goals, SDG 9, sustainable industrial development

JEL: L50, 014, Q50

\section{Introduction}

The idea of sustainable development refers to shaping the quality of life and the environment, with a focus on conditions for purposeful human activity. Effective links between the idea of economic development and the environment have been discussed

1 This research has been financed by the subsidy for maintaining research potential granted to the College of Economics, Finance and Law, Cracow University of Economics. 
internationally since the 1970s. Sustainable development tends to be considered with regard to environmental protection, but equally important areas of analysis include the economic dimension (economic policy instruments stimulating entities to use natural resources reasonably) and the technical aspect (new technologies saving the consumption of raw materials).

A tool for implementing sustainable development postulates is the green economy, based on the assumption of continuing socio-economic growth harmonised with the environment. The green economy aims to facilitate a decoupling of the economy from the environment so that production and consumption can occur within the planet's carrying capacity (UNEP 2019, p. 2). Emphasis is placed on transforming the economic model into a low-carbon, resource-efficient and socially-inclusive economy. The sector responsible for the largest share of energy consumption is industry, which includes refining, mining, manufacturing and construction (US Energy Information Administration 2019, p. 27).

From this perspective, sustainable industrial development is one of the pillars of the green economy. The concept starts from the assumption that a well-designed policy of structural changes can account for both productivity and environmental challenges (Altenburg and Assmann 2017, p. XII). The variation which is characteristic of the present-day world - also in terms of the organisation and structure of industrial production - drives the search for new solutions orientated towards the symbiosis of technological and economic progress with social and environmental advancement.

An additional challenge to a modern economy is to achieve the organisation of production that includes an economical approach to energy consumption and reduces health-related costs that stem from air pollution. The need for government action in order to maintain the transition to an inclusive green economy has gained in popularity, especially since the 2008 economic crisis. In this context, the greening of production methods and the more efficient use of natural resources are becoming increasingly noticeable.

The prospect of economic and social transformation towards a sustainable development model was defined at the global level by the UN in a document adopted by the member states in 2015 entitled Transforming our world: the 2030 Agenda for Sustainable Development. One of the 17 Sustainable Development Goals (SDG) defined at the time was Goal 9, which emphasizes the essence of sustainable industrial development, which will promote economic growth, greater social inclusion, and the rational use of natural resources (United Nations General Assembly 2015). The research topic of sustainable industrial development is receiving increasing attention (among others: European Commission 1999; Gilli et al. 2017; Seetoh and Ong 2008; Zodape et al. 2015). A literature review allows us to systematise the benefits, challenges and instruments for implementing sustainable industrial development. However, the empirical evidence concerning the transformation of economic structures towards sustainable industrial development is not widespread, especially in relation to Central and Eastern European countries. 
This paper tries to fill the gap by investigating the progress in achieving sustainable industrial development in the Czech Republic and Poland based on indicators adopted for SDG 9 and an assessment of the decoupling of manufacturing growth from energy consumption. The choice of countries surveyed was determined by their common history, economic structure, the stage of development and energy profile. The shared historical heritage of these countries with centrally planned economies had a great impact on the direction of the development of their industry. These countries invested in energy-intensive, high-carbon heavy industry, creating a unique energy culture based on the availability of cheap energy resources - coal, oil and natural gas (Pach-Gurgul and Ulbrych 2019, p. 181). Although a typical feature of those countries was the decrease in the case of manufacturing value added (MVA) in the 1990s, in the twenty-first century, an increase has been observed (Rachwał 2015, p. 580). The MVA share in total GDP is still relatively high in the Czech Republic and Poland, respectively $25 \%$ and $18 \%$ (UNIDO 2020). At the same time, the sector is one of the major energy users - consuming $28.4 \%$ of the total energy consumption in the Czech Republic and $22.6 \%$ in Poland (Enerdata-Odyssee 2020).

The structure of the paper is organised as follows: the first section introduces a literature review as well as the concept of sustainable industrial development and green industrial policy. Section two presents the results of the analysis regarding the implementation of SDG 9 in the field of industrial development in the Czech Republic and Poland. In the third section, the focus is on presenting the results of the study on the decoupling of manufacturing growth from energy consumption in the analysed economies. Subsequently, conclusions and implications are developed. The research methodology is based on two techniques: a literature review and a presentation of the results of the analysis of available statistical data for the period 2000-2018. The data used are aggregated at the level of 'manufacturing', which refers to industries belonging to section C defined by the International Standard Industrial Classification of All Economic Activities, Revision 4 (ISIC Rev.4).

\section{The concept of sustainable industrial development and green industrial policy}

Concerns about the future of our overexploited planet have been consistently emphasised since the 1970s. By publishing the 1972 report entitled The Limits to Growth, commissioned by the Club of Rome, a group of scientists questioned the then promoted forms of growth (Meadows et al. 2005). The report triggered a global discussion on major threats to future development in the form of physical and social constraints on growth in the world economy. In this context, an equally important study was the report of the World Commission on Environment and Development entitled Our Common Future, published in 1987. The document provided a framework for the integration of environmental policy into development strategies, stressing the need 
to create a strategy orientated to the dissemination and implementation of the concept of sustainable economic development on a global scale. In addition, it defined sustainable development as 'development that meets the needs of the present without compromising the ability of future generations to meet their own needs' (United Nations World Commission on Environment and Development 1987).

However, it can be assumed that sustainable development became a priority goal for the international community in 1992 when the UN Conference on Environment and Development called on governments to prepare national economic development strategies that incorporate environmental aspects (Allen and Clouth 2012, p. 4). The adopted Rio Declaration on Environment and Development contained principles that indicate a key role to be played by states in reducing and eliminating unsustainable patterns of production and consumption (United Nations 1992). Subsequently, the global financial crisis and its aftermath constituted another turning point in the debate on the need for green economic development. In response to increasing social and economic problems, the idea of Green Keynesianism was developed as an alternative development path, which referred to the traditional fiscal policy proposed by Keynes as an instrument for implementing environmental objectives (Harris 2013, pp. 2-3). The launch of the Green Economy Initiative by the UN Environment Programme (UNEP) in 2008 and the report entitled A Global Green Deal (Barbier 2009) marked the beginning of the current stage of defining a green economy, presented as an alternative to the brown economy. The most important characteristics that distinguish the new approach are as follows (Burchard-Dziubińska 2014, pp. 137-138):

- efforts to decouple economic growth from the use of raw materials;

- resource-saving production instead of resource-intensive production;

- the dominance of renewable energy sources over fossil fuels;

- high energy efficiency;

- sustainable consumption, in contrast to the common phenomenon of overconsumption.

The term green economy was first used in a study for the British government entitled Blueprint for a Green Economy (Pearce et al. 1989). A green economy is frequently defined as 'one that results in improved human well-being and social equity, while significantly reducing environmental risks and ecological scarcities' (UNEP 2011). In other words, the concept represents a radical transition to more efficient, environmentally friendly and resource-saving technologies to reduce emissions and mitigate the effects of climate change (Jänicke 2012, p. 15). During Rio+20, also known as the United Nations Conference on Sustainable Development in 2012, it was agreed that the green economy was an important tool of sustainable development, aimed at stimulating economic growth, eradicating employment and poverty, while maintaining the Earth's healthy ecosystem.

In addition, it was highlighted that capacity building, experience sharing, and the institutionalisation of global cooperation were of critical importance to implementing green economy policies (United Nations 2012). The green economy concept, pri- 
marily the discourse on green growth, has become a permanent item on the agenda of international institutions (European Commission 2010; OECD 2011; UNEP 2011; World Bank 2012). The paradigm refers to the Green New Deal postulates, which serve as catalysts for economic growth and which are, in turn, a contribution to the green economy. Green growth defines growth as being efficient in the use of natural resources, clean, thanks to reduced pollution and environmental impact, and resilient, due to the inclusion of natural hazards and the role of environmental management (World Bank 2012, p. 2).

However, the green economy is criticised on the basis of the doubtful assumption that green growth is determined by the decoupling of economic growth from the use of resources. In fact, there is evidence indicating relative decoupling of GDP growth trends from energy consumption and reduced energy intensity in a number of economies (Jackson 2009, p. 109). Nevertheless, the main problem remains: total energy consumption is on the increase, although at a rate lower than that of GDP growth. Some authors point to the need for absolute decoupling, and they emphasise the transitionary potential of the green economy agenda. Moving to greener forms of growth, even if they simply constitute relative decoupling, appears to be the only feasible first step towards a post-growth economy (Ferguson 2014, p. 6). In this context, it is worth stressing the need for an environmentally sustainable production method and a more efficient use of resources, in accordance with the 'producing more with less' principle. As a result, it is possible to adopt the following definition of sustainable industrial development, taking into account three parameters (Zodape et al. 2015, p. 112):

- the growth of endogenous productive capacities, especially the capacity for innovation;

- an improvement in the environmental performance of industry;

- improvements in living standards and a reduction of inequality, especially via growth in the quantity and remuneration of jobs in the manufacturing sector.

According to the Lima Declaration, the United Nations Industrial Development Organisation (UNIDO) indicates that inclusive and sustainable industrial development (ISID) is a key driver of successful integration of the economic, social and environmental dimensions, crucial for full implementation of sustainable development for the benefit of future generations (UNIDO 2013).

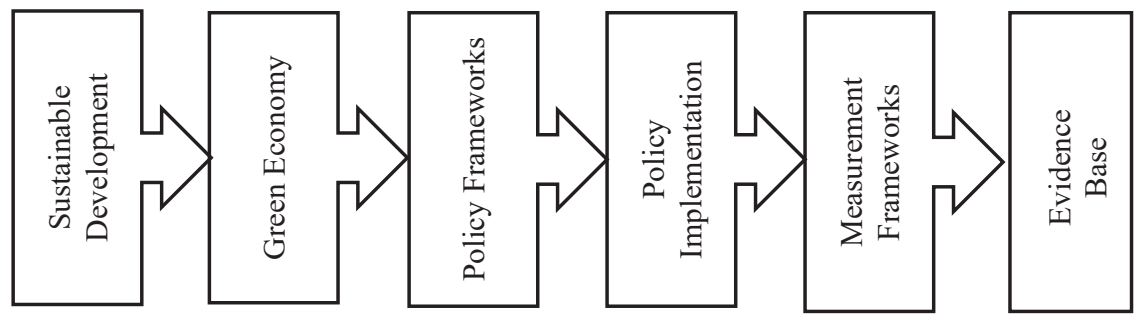

Figure 1. Green growth monitoring framework Source: Georgeson et al. 2017, p. 4. 
Therefore, the greening of industry is a method for achieving sustainable economic growth through policymaking, improved processes of industrial production and resource-efficient productivity. But it involves the preparation of an appropriate legal framework and coordinated efforts at various levels of administration as well as across policies. Figure 1 presents a green growth monitoring framework, with a focus not only on establishing certain norms and standards, but also on designing measurement methods. With regard to the implementation of the idea of sustainable industrial development, industrial policy is of relevance. As in the case of traditional industrial policy, there is no widely accepted definition of green industrial policy. However, it can be assumed that it comprises all economic policy tools orientated towards structural adjustments in the economy for the needs of sustainable development (Lütkenhorst et al. 2014, p. 1). Any attempt to justify the application of green industrial policy must take account of the main conditions thereof (Partnership for Action on Green Economy 2017, pp. 10-13; Rodrik 2014, pp. 470-471; World Bank 2012, pp. 66-67):

- market imperfections;

- externalities.

The need for economic intervention tends to be justified by the existence of market imperfections: the market concerned ceases to ensure - in terms of Pareto optimality - utility maximisation and optimal allocation of resources. It results from the lack of asymmetry of information, capital market imperfections and non-coordinated investment decisions. Incomplete information may cause social inefficiency of resource management. Collecting information is time-consuming and costly; hence, it is desirable for public institutions to intervene for the reinforcement and coordination of the information flow system. As regards the capacity of businesses (especially small and medium-sized enterprises (SMEs)) to incur environmental investment costs, it is frequently curbed by capital market imperfections. It gives rise to a need to define necessary framework conditions for easier access to funding. Furthermore, the benefits of technological improvements in the production process are not fully taken over by pioneering undertakings that invest heavily in research and development. It seems vital to monitor technology diffusion and to subsidise research and development activities in areas characterised by high innovation potential.

Externalities are caused by private undertakings that infringe on the environment (air and water pollution, noise, congestion). As a burden on other entities, they result in differences in the balance of marginal costs and marginal utilities for individuals and society. An example of economic policy measures in that regard might be taking steps to reduce negative externalities by adopting environmental protection legislation.

The above arguments for public intervention and remedy actions are mostly justified in situations that eliminate behaviour patterns of undertakings that counteract public utility maximisation. Furthermore, properly designed green industrial policy that makes use of market incentives can intensify the process of implementing new 
technologies. By stimulating innovation, strict environmental regulations can actually enhance competitiveness and improve the competitive advantage of domestic companies (Porter and van der Linde 1995, p. 98).

\section{Monitoring Sustainable Development Goal 9 in the Czech Republic and Poland}

As emphasised before, the social and economic consequences of the financial crisis revealed the need to re-think economic theory and practice, which resulted in the renaissance of industrial policy. In addition, the present-day environmental challenges draw greater attention to industrial capacity to change current production and consumption models. The literature provides evidence that structural economic transition, through productivity improvements, which fosters economic diversification and builds green industries, is of key significance to boosting economic growth, job creation and forming structures necessary to achieve common welfare (Li 2015, p. 447).

Naturally, the debate should address not only the need to increase the share of industry in the economy, but also how industry actually contributes to sustainable development in all its dimensions - at the economic, social and environmental levels. The foundations for such a vision of industrial development were adopted by the UNIDO Member States in the Lima Declaration (the ISID concept) and subsequently included in the UN agenda, i.e. the 2015 development programme entitled Transforming Our World: The 2030 Agenda for Sustainable Development. The resolution introduced 17 goals (Sustainable Development Goals - SDG) as the main points of reference for sustainable development policy until 2030. ISID was included in the global development programme as SDG 9, calling to 'Build resilient infrastructure, promote inclusive and sustainable industrialisation and foster innovation'. Table 1 presents an overview of the targets and indicators adopted for SDG 9 in the field of sustainable industrialisation.

SDG 9.2 emphasises the importance of industrial production in generating value added and employment in an economy, according to Kaldor's studies that indicate a positive correlation between increased industrial production and GDP variations (Kaldor 1967). There is empirical evidence corroborating the relationship between economic growth and the size and expansion of the production sector. Industrial production makes it possible to attain faster productivity growth and drives technological changes (UNIDO 2019, p. 15).

The first dimension of Goal 9.2 is composed of two indicators: MVA as a proportion of GDP and MVA per capita, with their values for the Czech Republic and Poland presented in Figures 2 and 3, respectively. A widespread global phenomenon in developed countries is deindustrialisation, i.e. a relative decrease in industry's share of the economy (Ulbrych 2018, p. 459). 
Table 1. Targets and indicators for SDG 9 in the field of sustainable industrialization

\begin{tabular}{|c|c|c|}
\hline Goal & Proposed indicator & Concept and rationale \\
\hline \multirow{3}{*}{$\begin{array}{l}9.2 \text { Promote inclusive and sus- } \\
\text { tainable industrialization and, } \\
\text { by } 2030 \text {, significantly raise in- } \\
\text { dustry's share of employment } \\
\text { and gross domestic product, } \\
\text { in line with national circum- } \\
\text { stances, and double its share } \\
\text { in the least developed coun- } \\
\text { tries. }\end{array}$} & $\begin{array}{l}\text { Manufacturing value added } \\
\text { (MVA) as a proportion of GDP }\end{array}$ & $\begin{array}{l}\text { It reflects the role of industrial } \\
\text { production in the economy. }\end{array}$ \\
\hline & MVA per capita & $\begin{array}{l}\text { It is the main indicator } \\
\text { of a country's industrialisation } \\
\text { level, adjusted to the size of its } \\
\text { economy measured by popu- } \\
\text { lation. }\end{array}$ \\
\hline & $\begin{array}{l}\text { Manufacturing employment } \\
\text { as a proportion of total } \\
\text { employment }\end{array}$ & $\begin{array}{l}\text { It measures the capacity } \\
\text { of manufacturing to absorb ex- } \\
\text { cess labour from other sectors. } \\
\text { In developed countries, the } \\
\text { workforce is expected to de- } \\
\text { crease in industrial production } \\
\text { as a result of the automation } \\
\text { of various processes. }\end{array}$ \\
\hline \multirow{2}{*}{$\begin{array}{l}9.3 \text { Increase the access } \\
\text { of small-scale industrial and } \\
\text { other enterprises, in particu- } \\
\text { lar, in developing countries, } \\
\text { to financial services, including } \\
\text { affordable credit, and their in- } \\
\text { tegration into value chains and } \\
\text { markets. }\end{array}$} & $\begin{array}{l}\text { Proportion of small-scale } \\
\text { industries in total industry } \\
\text { value added }\end{array}$ & $\begin{array}{l}\text { Despite the minor contribu- } \\
\text { tion of small-scale industries } \\
\text { to total value added generated } \\
\text { by industry, they play a signifi- } \\
\text { cant role in job creation, espe- } \\
\text { cially in developing countries. }\end{array}$ \\
\hline & $\begin{array}{l}\text { Proportion of small-scale } \\
\text { industries with a loan or line } \\
\text { of credit }\end{array}$ & $\begin{array}{l}\text { The indicator shows the extent } \\
\text { of services supplied by finan- } \\
\text { cial institutions to small-scale } \\
\text { industries, with limited access } \\
\text { to financial services, particular- } \\
\text { ly in developing countries. }\end{array}$ \\
\hline \multirow{2}{*}{$\begin{array}{l}9.4 \text { By } 2030 \text {, upgrade infra- } \\
\text { structure and retrofit indus- } \\
\text { tries to make them sustainable, } \\
\text { with increased resource-use } \\
\text { efficiency and greater adop- } \\
\text { tion of clean and environmen- } \\
\text { tally sound technologies and } \\
\text { industrial processes, with all } \\
\text { countries taking action in ac- } \\
\text { cordance with their respective } \\
\text { capabilities. }\end{array}$} & $\begin{array}{l}\text { Carbon dioxide emissions from } \\
\text { manufacturing }\end{array}$ & $\begin{array}{l}\text { Assuming that } \mathrm{CO}_{2} \text { emissions } \\
\text { account for ca. } 80 \% \text { of total } \\
\text { greenhouse gas emissions from } \\
\text { production processes, the in- } \\
\text { dicator adopted is the level } \\
\text { of } \mathrm{CO}_{2} \text { emissions from manu- } \\
\text { facturing. }\end{array}$ \\
\hline & $\begin{array}{l}\text { Carbon dioxide emissions per } \\
\text { unit of MVA }\end{array}$ & $\begin{array}{l}\text { The indicator applied is the } \\
\text { level of } \mathrm{CO}_{2} \text { emissions per unit } \\
\text { of value added, measuring the } \\
\text { carbon dioxide emission inten- } \\
\text { sity of manufacturing. }\end{array}$ \\
\hline $\begin{array}{l}\text { 9.b Support domestic technol- } \\
\text { ogy development, research and } \\
\text { innovation in developing coun- } \\
\text { tries, including ensuring a con- } \\
\text { ducive policy environment for, } \\
\text { inter alia, industrial diversifica- } \\
\text { tion and value addition to com- } \\
\text { modities. }\end{array}$ & $\begin{array}{l}\text { Medium and high-tech (MHT) } \\
\text { industry value added in total } \\
\text { value added }\end{array}$ & $\begin{array}{l}\text { Industrial development in- } \\
\text { volves a structural transition } \\
\text { from resource-based low-tech- } \\
\text { nology activities to those char- } \\
\text { acterised by higher technology } \\
\text { intensity and increased labour } \\
\text { productivity. }\end{array}$ \\
\hline
\end{tabular}

Source: own elaboration based on UNIDO, https://stat.unido.org/SDG (accessed: 15.02.2020). 
Nevertheless, the process is not observed in countries concerned where MVA as a proportion of GDP has been on the increase since 2000. In the period covered, the share of manufacturing in GDP, measured by value added, rose from $15.4 \%$ to $25.5 \%$ and from $11.1 \%$ to $18.8 \%$ in the Czech and Polish economies, respectively. In comparison, in Germany - where the industrial sector plays a major role - the indicator went up from $19.5 \%$ to $21.4 \%$.

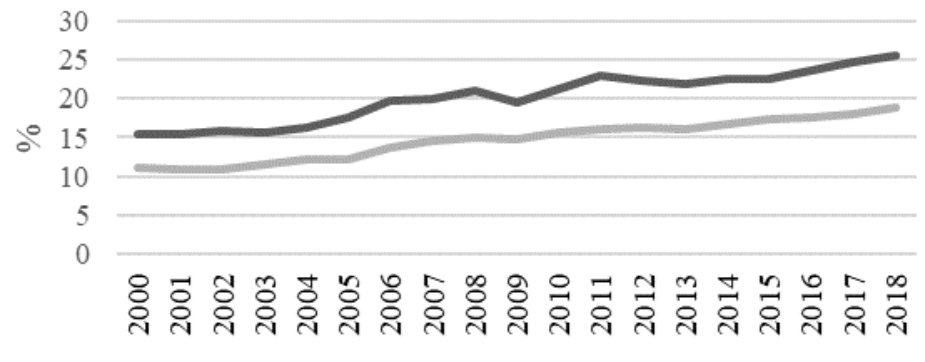

$\longrightarrow$ Czech Republic $\longrightarrow$ Poland

Figure 2. MVA as a proportion of GDP (\%)

Source: own dataset based on UNIDO, https://stat.unido.org/SDG (accessed: 10.02.2020).

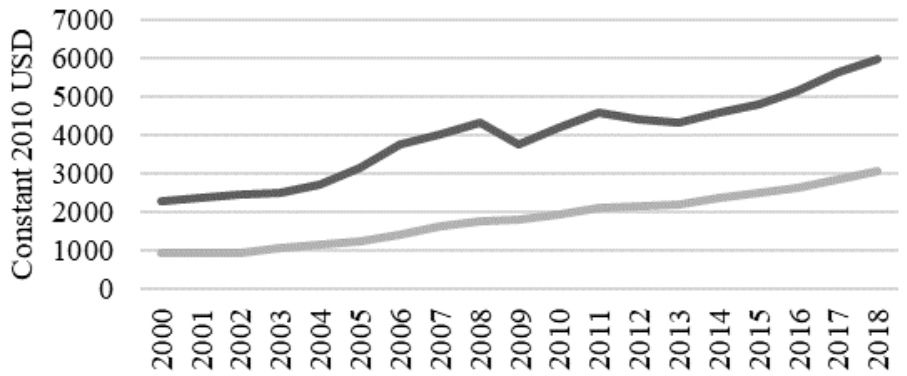

Czech Republic $\longrightarrow$ Poland

Figure 3. MVA per capita (constant 2010 USD)

Source: own dataset based on UNIDO, https://stat.unido.org/SDG (accessed: 10.02.2020).

A similar upward trend can be seen in the case of MVA per capita: in 2018, it was $263 \%$ of the 2000 level in the Czech Republic and 327\% in Poland. However, despite the rise, in 2018, MVA per capita in the Czech Republic - at USD 5,976 - represented slightly more than half of the respective indicator for Germany (USD 10,268). As regards the Polish economy, the proportion was approximately one-third. The third and last indicator for Goal 9.2 is manufacturing employment as a proportion of total employment, with relevant changes illustrated in Figure 4. In 2000-2017, manufacturing employment remained relatively stable, generating more than one-fourth of jobs in the Czech Republic and around one-fifth in Poland. Therefore, the sector is vital for the labour market in both countries. In addition, throughout the period covered sim- 
ilar relative levels of employment were accompanied by rising MVA per capita, which suggests an increase in productivity.

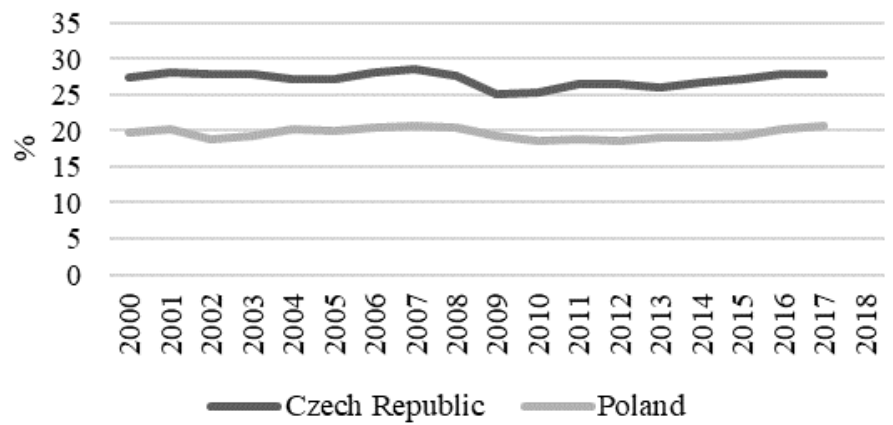

Figure 4. Manufacturing employment as a proportion of total employment

Source: own dataset based on UNIDO, https://stat.unido.org/SDG (accessed: 10.02.2020).

In the long term, however, technological development, automation and digitisation can be expected to change employment opportunities towards rising demand for a high-skilled workforce. At the same time, the existing advantage of Central and Eastern European countries, which is based on relatively low labour costs, is not sufficient. Manufacturing is characterised by major pay gaps (in terms of net monthly earnings) in the countries of the region in relation to Northern and Western Europe (Drahokoupil and Piasna 2018, pp. 12-13). Modern and internationally competitive industrial activities involve continuous upgrading of products and increased production capability.

A major challenge faced by countries such as the Czech Republic and Poland becomes skills mismatch, defined as the gap between a worker's skills and the labour market's demands (The Adecco Group 2018, p. 18). Empirical analysis identifies an inverted U-shaped relationship with the share of manufacturing employment first rising and then falling with income per capita. Thus, deindustrialisation measured by a decrease in the share of production in total employment becomes a key policy issue. The phenomenon may have a favourable effect on the economy if resources are shifted to highly productive activities such as modern services. However, it may also exert a negative influence as a result of human capital moving to low-productivity and low-wage activities or informal services (UNIDO 2017, p. 12).

Two indicators were adopted for the measurement of Goal 9.3 (Table 1). One of those, i.e. the proportion of small-scale industries in total value added, emphasises the role of small and medium-sized enterprises in the economy, particularly in the context of job creation and self-employment. The other - the proportion of small-scale industries with a loan or line of credit - was selected on account of frequent difficulties faced by small businesses that stem from limited access to financial services. 


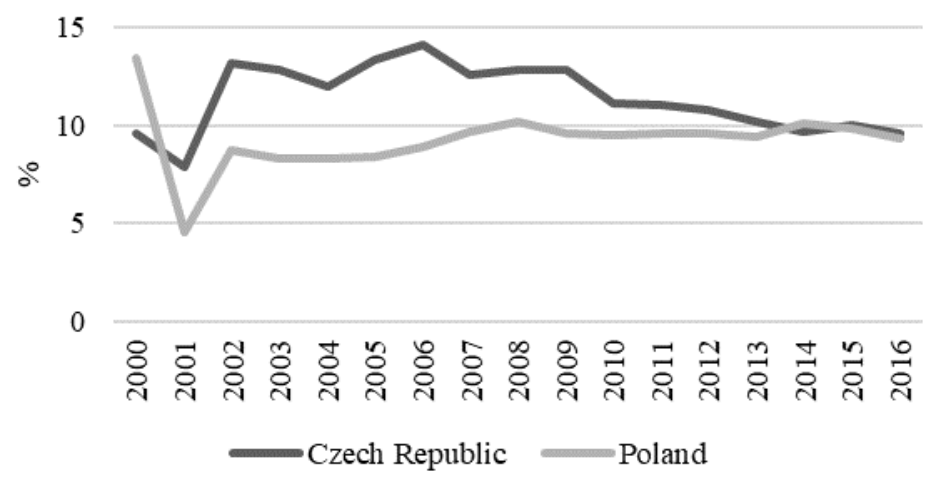

Figure 5. Proportion of small-scale industries in total industry value added Source: own dataset based on UNIDO, https://stat.unido.org/SDG (accessed: 10.02.2020).

Although financing is a key element in the development of the SME sector, the indicator in question entails a major problem with obtaining information, due to the lack of publicly available, comparable data (UNCTAD 2020).

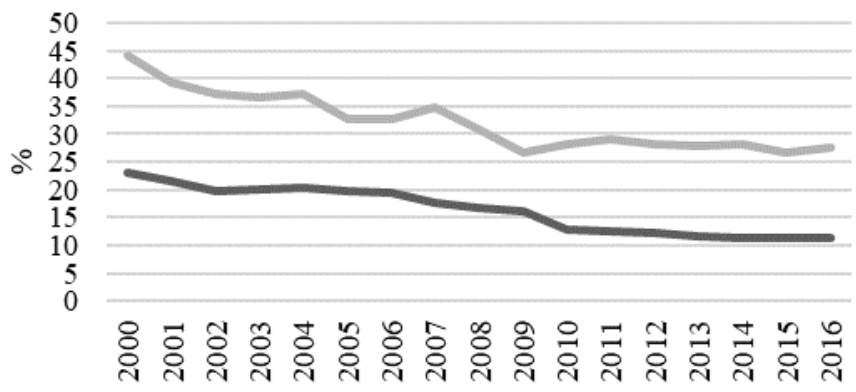

Czech Republic $\longrightarrow$ Poland

Figure 6. $\mathrm{CO}_{2}$ emissions from manufacturing (\% of total fuel combustion)

Source: own dataset based on UNIDO, https://stat.unido.org/SDG (accessed: 10.02.2020).

But the analysis of aggregated data in Figure 5, concerning the first indicator of Goal 9.3, demonstrates that in the last years of the period covered, the proportion was very similar in both countries, at approximately $10 \%$. Throughout the period under examination, however, both economies showed different trends: in the Czech Republic, there was a minor fall (by 3.6 percentage points) after 2002, whereas the opposite was the case in Poland.

In the context of Goal 9.4, UNIDO publishes data on greenhouse gas emissions. Based on the assumption that $\mathrm{CO}_{2}$ emissions account for $80 \%$ of total emissions from production processes, the focus is on $\mathrm{CO}_{2}$ emissions in total fuel combustion (Figure 6) and $\mathrm{CO}_{2}$ emissions per unit of value added (Figure 7). 


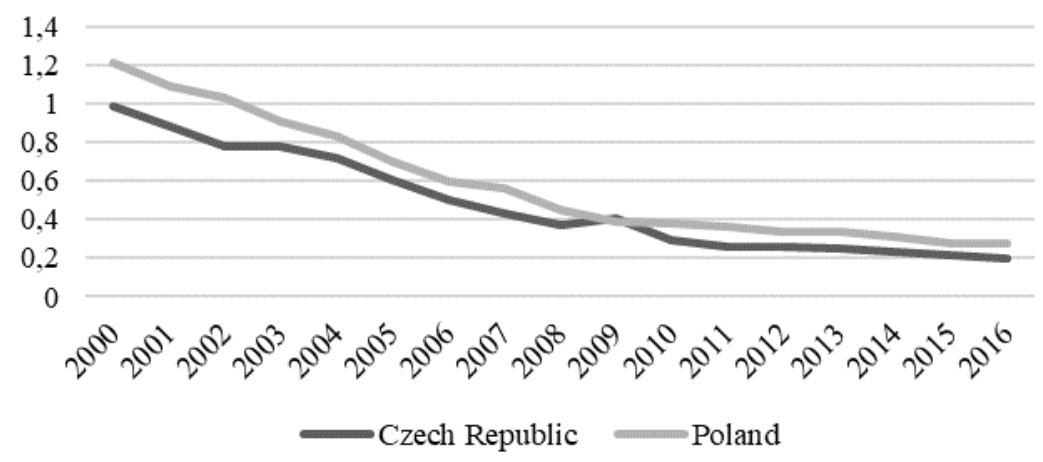

Figure 7. $\mathrm{CO}_{2}$ emission per unit of value added (kilogrammes of $\mathrm{CO}_{2}$ per constant 2010 USD) Source: own dataset based on UNIDO, https://stat.unido.org/SDG (accessed: 10.02.2020).

The analysis of movements in the value of the former indicator shows a gradual decrease to $11.2 \%$ in the Czech Republic and 27.5\% in Poland. The latter indicator measures $\mathrm{CO}_{2}$ emission intensity, resulting from the energy mix used, the technology employed and its energy efficiency. The indicator is on the decrease in both economies. While in the period 2000-2009, the annual average rate of change was $12 \%$ in Poland and $10 \%$ in the Czech Republic, the following years witnessed a deceleration in those positive developments.

The measure of Goal $9 \mathrm{~b}$ shows the relative importance of medium- and high-tech industry (MHT) in manufacturing. An increased share of MHT in total MVA indicates not only improved technological intensity of the production sector, but it also reflects its capability to introduce new technologies to other sectors (UNIDO 2019, p. 46). Figure 8 illustrates changes in the structure of manufacturing value added, including MHT, in the Czech Republic and in Poland. Throughout the period covered, the Czech economy performed better in terms of the indicator under examination.

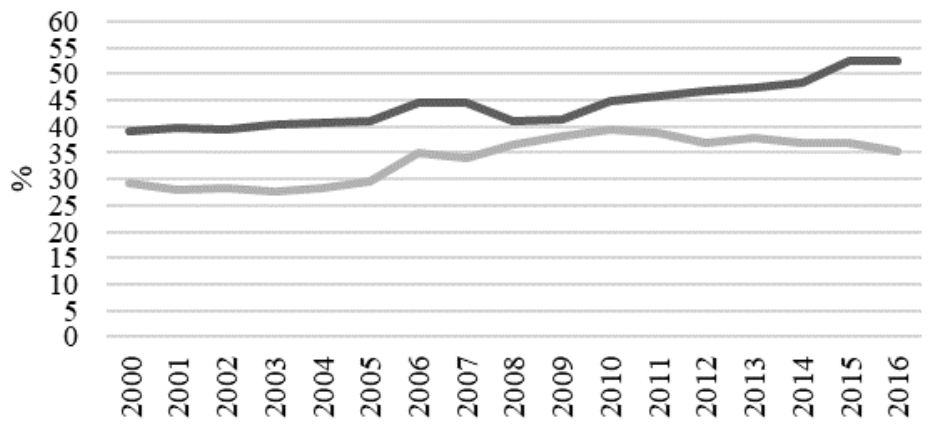

Czech Republic $=$ Poland

Figure 8. Medium and high-tech industry value added in total value added

Source: own dataset based on UNIDO, https://stat.unido.org/SDG (accessed: 10.02.2020). 
Between 2000 and 2016, the proportion of MHT in the total value added of Czech manufacturing rose by 13 percentage points, with an acceleration of the upward trend noted after 2010. During the whole period in question, the respective share for Poland went up by 6 percentage points; however, the proportion of MHT in total MVA started to drop after 2010. It is worth noting that the share of MHT in MVA in industrialised economies such as Germany exceeds $60 \%$.

\section{Decoupling manufacturing growth from energy consumption in the Czech Republic and Poland}

Technological progress is the foundation for efforts to achieve environmental objectives, e.g. increasing resource productivity and energy efficiency. Cleaner and more resource-saving methods of production may gradually lead to the decoupling of economic growth from environmental degradation. The term decoupling refers to breaking the link between 'environmental bads and economic goods'. It occurs when the growth rate of an environmental pressure is less than that of its economic driving force over a given period. Decoupling can be either absolute or relative. The first case - absolute decoupling - is recorded when the environmentally relevant variable is stable or decreasing while the economic driving force is growing. Decoupling is said to be relative when the growth rate of the environmentally relevant variable is positive but less than the growth rate of the economic variable (OECD 2002, p. 4).

Investigating this process and enriching the above list of indicators with trends in energy consumption by manufacturing in the studied economies seems reasonable and interesting. Figure 9 presents the relationship between MVA, final energy consumption and the energy intensity of manufacturing in the Czech Republic and Poland. Comparisons across time series present the indicator as an index compared with 2000. 


\section{Czech Republic}
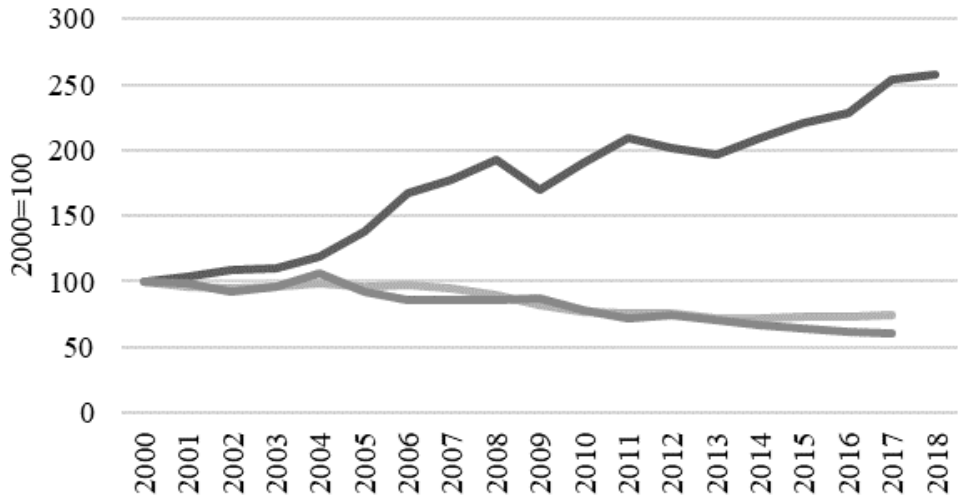

- MVA Energy consumption $\longrightarrow$ Energy intensity

\section{Poland}

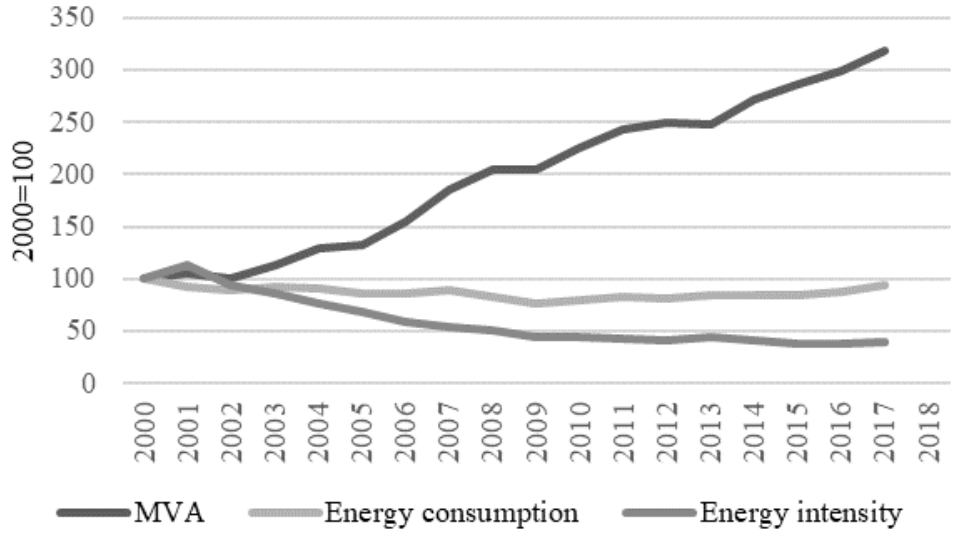

Figure 9. Trends in MVA, final energy consumption and energy intensity of manufacturing in the Czech Republic and Poland

Source: own dataset based on Enerdata-Odyssee, https://odyssee.enerdata.net/database/ (accessed: 15.02.2020).

Between 2000 and 2017, energy intensity in the manufacturing sector, i.e. the ratio between its final energy consumption and the value added at a constant price, decreased in both economies - in the Czech Republic by $39 \%$, and in Poland by $61 \%$. This decrease was continuous during the entire period, with an average annual decrease of $2.9 \%$ in the Czech Republic and 5.41\% in Poland. The 2000-2017 period is characterised by high MVA growth and a steady decline in energy consumption in the Czech Republic. The value of MVA increased 2.5 times, while energy consumption fell by $25 \%$ from 9.7 to 7.3 Millions of tonnes of oil equivalent (Mtoe). Similarly, in Poland, final energy consumption decoupled from MVA growth: while MVA value grew by more than three times, energy consumption decreased by $6.4 \%$. As a consequence, energy 
intensity fell during this period. Thus, absolute decoupling was observed in both countries. However, it is worth noting that while the decrease in intensity in the Czech Republic is quite even, in Poland the largest decrease occurred in the period 2000-2009 (by $56 \%$ ) and in the following years, the improvement in energy intensity was fairly constant.

\section{Conclusion}

The idea of sustainable development has become widely accepted, also in the aspect of industrial development. The review of the literature allowed us to define and organize concepts such as the Green New Deal, the green economy, sustainable development, sustainable industrial development and green industrial policy. The hierarchy between these terms indicates the following relationships: the Green New Deal is a catalyst and contributor (by stimulating green growth) to the green economy, which is a means of achieving sustainable development. Pursuing responsible and sustainable development, the UN has urged the decoupling of economic growth from environmental impacts. One of the key elements of this process is the improvement of manufacturing organisations towards sustainable industrial development. Green industrial policy is conscious state interference in market processes aimed at implementing the assumptions of sustainable industrial development. The UN emphasises that industry must be made both green and inclusive, and therefore the indicators adopted under SDG 9 refer to both dimensions.

According to the literature review, it should be stated that sustainable industrial development should be considered one that causes:

- the growth of manufacturing capacity and the competitiveness of this sector,

- employment creation,

- improvement in environmental performance.

The first dimension, i.e. manufacturing capabilities, was measured as the share of MVA in GDP and MVA per capita. SDG Target 9.2 aims to significantly increase the level (it applies primarily to developing countries). In the case of the Czech and Polish economies, the absolute manufacturing value added increases, which is reflected in the higher MVA per capita. In both countries, the value of this indicator increased about three times. At the time, however, MVA per capita in the Czech Republic is almost twice as high as in Poland. The relative importance of manufacturing is also growing, from $10.9 \%$ to $18.8 \%$ of GDP in Poland, and from $15.4 \%$ to $25.5 \%$ of GDP in the Czech Republic. The important drivers of manufacturing competitiveness are micro, small and medium enterprises, which are a significant source of value added and jobs. The proportion of small-scale industries in total industry value added is very similar in both countries, at approximately $10 \%$. This share is similar to that in the developed, large EU economies (e.g. France and Germany, it is also worth paying attention to the decreasing proportion of SMEs in the manufacturing sector in these countries recent- 
ly). Another indicator that directly determines the level of competitiveness of industrial production is medium and high-tech industry value added in total value added. In this respect, the Czech Republic is improving, while Poland has experienced a slow decline since 2010.

The second dimension, i.e. the share of manufacturing employment in total employment, reflects the share of the population that directly benefits from the manufacturing sector. In the Czech Republic and Poland, in contrast to the changes recorded in most developed economies, the share of the workforce employed in manufacturing is stable over the period (27\% in the Czech Republic and 20\% in Poland). This phenomenon can be explained by the growing production activity and participation of both economies in global value chains.

The third dimension underlines the need to reduce manufacturing pressure on the environment. Despite the increased activity in manufacturing, final energy consumption in this sector has decreased in both the Czech Republic and Poland (respectively by 1.1 and 2.4 Mtoe). As a result, energy intensity in manufacturing fell in both countries during the period.

Similarly, $\mathrm{CO}_{2}$ emission intensity is on the decrease in both economies. Despite the progress, the economies are still among the most carbon-intensive in the EU. The Czech Republic and Poland have one of the highest greenhouse gas emission per capita in the EU - 12.2 and 11.0 tonnes, respectively, compared to an EU average of 8.5 in 2018 (Eurostat 2020). These trends resulted in absolute decoupling; however, the pace of these positive changes was faster until 2010 and then slowed down, especially in Poland.

In summary, both economies are transit countries with a high share of manufacturing in GDP, and therefore a developing competitive and sustainable industrial base is of crucial importance. An important issue is the modernization of production processes and an increase in the share of medium and high-tech industry value added in total value added. A key challenge for these economies is to curb greenhouse gas emissions through decarbonising power generation to move closer to climate neutrality. Such tendencies should be associated with energy savings and structural changes (towards less energy-intensive technology), which would decrease consumption in the long run. In this regard, an appropriate policy framework is needed that will reduce the scale of externalities of industrial activity. Additionally, industrial policy is central in fostering the transmission of new technologies in order for workers to be able to enter more productive manufacturing sectors, to improve competitiveness and to upgrade the position of economies in global value chains. Policy documents developed by national governments have defined goals for the development that follow the idea (Office of the Government of the Czech Republic, Department of Sustainable Development 2017; Ministry of Economic Development of Poland 2017); however, more emphasis on actions aimed at implementing the SDG 9 can be seen in the Polish strategy. 


\section{References}

Allen, C., Clouth, S. (2012), A guidebook to Green Economy, UNDESA, New York.

Altenburg, T., Assmann, C. (eds.) (2017), Green Industrial Policy. Concept, Policies, Country Experiences. Geneva, UN Environment, German Development Institute, Bonn.

Barbier, E. (2009), Rethinking the Economic Recovery: A Global Green New Deal, Report prepared for the Green Economy Initiative of UNEP, United Nations Environment, University of Wyoming, Laramie.

Burchard-Dziubińska, M. (2014), Wdrażanie zielonej gospodarki jako odpowiedź Unii Europejskiej na trudności rozwojowe, "Acta Universitatis Lodziensis. Folia Oeconomica", 3 (303), pp. 135-150.

Drahokoupil, J., Piasna, A. (2018), What is behind low wages in central and eastern Europe?, "Post-Communist Economies", 30(4), pp. 421-439. https://doi.org/10.10 80/14631377.2018.1442037

Enerdata-Odyssee (2019), Energy Efficiency Indicators in Europe Database. http://www .odyssee-indicators.org (accessed: 10.01.2019).

European Commission (1999), Commission Staff Working Paper on Sustainable Industrial Development, SEC (1999)1729.

European Commission (2010), Europe 2020: A European strategy for smart, sustainable and inclusive growth, COM (2010)2020.

Eurostat (2020), Greenhouse gas emissions per capita. https://ec.europa.eu/eurostat/web /products-datasets/-/T2020_RD300 (accessed: 9.02.2019).

Ferguson, P. (2015), The green economy agenda: business as usual or transformational discourse?, "Environmental Politics", 24:1, pp. 17-37. https://doi.org/10.1080/0964 4016.2014.919748

Georgeson, L., Maslin, M., Poessinouw, M. (2017), The global green economy: a review of concepts, definitions, measurement methodologies and their interactions, "Geo: Geography and Environment”, 4 (1), pp. 1-23. https://doi.org/10.1002/geo2.36

Gilli, M., Giovanni, M., Mazzanti, M., Francesco, N. (2017), Sustainable development and industrial development: manufacturing environmental performance, technology and consumption/production perspectives, "Journal of Environmental Economics and Policy", 6:2, pp. 183-203. https://doi.org/10.1080/21606544.2016.1249413

Harris, J.M. (2013), Green Keynesianism: Beyond Standard Growth Paradigms, Global Development and Environment Institute Working Paper, No. 13-02, GDAE, Tufts University.

Jackson, T. (2009), Prosperity without growth: economics for a finite planet, Earthscan, London. https://doi.org/10.1260/0958-305X.22.7.1013

Jänicke, M. (2012), Green growth: from a growing eco-industry to economic sustainability, "Energy Policy", 48, pp. 13-21. https://doi.org/10.1016/j.enpol.2012.04.045

Kaldor, N. (1967), Strategic Factors in Economic Development, Cornell University Press, Ithaca.

Li, Y. (2015), Towards Inclusive and Sustainable Industrial Development, "Development”, 58, pp. 446-451. https://doi.org/10.1057/s41301-016-0055-8 
Lütkenhorst, W., Altenburg, T., Pegels, A., Vidican, G. (2014), Green Industrial Policy. Managing Transformation under Uncertainty, Deutsches Institut für Entwicklungspolitik. Discussion Paper, 28. https://doi.org/10.13140/2.1.1706.7529

Meadows, D.H., Randers J., Meadows D.L. (2005), Limits to Growth. The 30-Year Update, Earthscan, London.

Ministry of Economic Development of Poland (2017), The Strategy for Responsible Development for the period up to 2020 (including the perspective up to 2030), Warsaw.

OECD (2002), Indicators to measure decoupling of environmental pressure from economic growth, SG/SD (2002)1/Final. http://www.oecd.org/officialdocuments/publicdisp laydocumentpdf/?doclanguage $=$ en $\&$ cote $=s g / s d(2002) 1 /$ final (accessed: 9.02 .2019$)$.

OECD (2011), Towards Green Growth: Monitoring Progress. OECD Indicators. https:// www.oecd.org/greengrowth/48224574.pdf (accessed: 9.02.2019).

Office of the Government of the Czech Republic, Department of Sustainable Development (2017), Strategic Framework Czech Republic 2030. https://www.cr2030.cz/str ategie/wp-content/uploads/sites/2/2018/05/Strategic_Framework_CZ2030_graphi c2.compressed.pdf (accessed: 13.07.2020).

Pach-Gurgul, A., Ulbrych, M. (2019), Progress of V4 Countries towards the EU's Climate and Energy Targets in the Context of Energy Security Improvement, "Entrepreneurial Business and Economics Review”, 7 (2), pp. 175-197. https://doi.org/10 .15678/EBER.2019.070210

Partnership for Action on Green Economy (PAGE) (2017), Green Industrial Policy and Trade: A Tool-Box. https://www.un-page.org/files/public/gita_manual_150ppi_full 3.pdf (accessed: 9.02.2019)

Pearce, D., Markandya, A., Barbier, E. (1989), Blueprint for a Green Economy, Earthscan Publications Ltd., London.

Porter, M.E., Linde, C. van der (1995), Toward a New Conception of the Environment-Competitiveness Relationship, "Journal of Economic Perspectives", 9 (4), pp. 97-118. http://dx.doi.org/10.1257/jep.9.4.97

Rachwał, T. (2015), Structural Changes in Polish industry after 1989, "Geographia Polonica”, 88 (4), pp. 577-605. http://dx.doi.org/10.7163/GPol.0035

Rodrik, D. (2014), Green Industrial Policy, "Oxford Review of Economic Policy”, 30 (3), pp. 469-491. https://doi.org/10.1093/oxrep/gru025

Seetoh, K.C., Ong, A.H.F. (2008), Achieving Sustainable Industrial Development Through a System of Strategic Planning and Implementation: The Singapore Model, [in:] T.C. Wong, B. Yuen, C. Goldblum (eds.) Spatial Planning for a Sustainable Singapore, Springer, Dordrecht. https://doi.org/10.1007/978-1-4020-6542-2_7

The Adecco Group (2018), $4^{\text {th }}$ Industrial Revolution in Central and eastern Europe. http://www.adecco.si/wp-content/uploads/2018/07/Inovantage-June-18th-Adecco .pdf (accessed: 9.02.2019).

Ulbrych, M. (2018), The Role and Importance of Manufacturing Trade Cooperation of the Visegrad Group Countries, Proceedings of $18^{\text {th }}$ International Joint Conference: Central and Eastern Europe in the Changing Business Environment, Oeconomica Publishing House, Bratislava, pp. 455-466.

UNCTAD (2020), Development and Globalization. Facts and Figures. https://stats.unc tad.org/Dgff2016/prosperity/goal9/target_9_3.html (accessed: 10.01.2019). 
UNEP (2011), Towards a Green Economy: Pathways to Sustainable Development and Poverty Eradication - A Synthesis for Policy Makers. http://www.unep.org/greenec onomy (accessed: 9.02.2019).

UNEP (2019), Shades of green: an introduction to the green economy for parliamentarians, Issue Brief, February. https://www.unenvironment.org/resources/publication /shades-green-introduction-green-economy-parliamentarians-issues-brief (accessed: 9.02.2019).

UNIDO (2013), Lima Declaration: Towards inclusive and sustainable industrial development, 15 UNIDO General Conference Lima-Peru, 2-6.12.13, Resolution GC.15/ RES1.

UNIDO (2017), Structural Change for Inclusive and Sustainable Industrial Development, UNIDO, Vienna.

UNIDO (2019), Statistical Indicators of Inclusive and Sustainable Industrialisation. Biennial Progress Report 2019, UNIDO, Vienna.

UNIDO (2020), Statistical Databases. https://www.unido.org/researchers/statistical-d atabases (accessed: 10.01.2019).

United Nations (1992), Rio Declaration on Environment and Development, The United Nations Conference on Environment and Development, Rio de Janeiro, Brazil, 3-14 June 1992, A/CONE.151/26 (vol. I). https://www.un.org/en/development/desa /population/migration/generalassembly/docs/globalcompact/A_CONF.151_26_Vol .I_Declaration.pdf (accessed: 9.02.2019).

United Nations (2012), The Future we want. Outcome document of the United Nations Conference on Sustainable Development, Rio de Janeiro, Brazil, 20-22 June 2012. https://sustainabledevelopment.un.org/content/documents/733FutureWeWant.pdf (accessed: 9.02.2019).

United Nations General Assembly (2015), Transforming Our World: The 2030 Agenda for Sustainable Development, A/RES/70/1.

United Nations World Commission on Environment and Development (1987), Report of the World Commission on Environment and Development: Our Common Future, Oxford University Press, Oxford.

US Energy Information Administration (2019), International Energy Outlook 2019 with projections to 2050, Office of Energy Analysis, U.S. Department of Energy, Washington.

World Bank (2012), Inclusive Green Growth. The Pathway to Sustainable Development, The World Bank, Washington. https://openknowledge.worldbank.org/handle/109 86/6058 (accessed: 9.02.2019).

Zodape, H., U Patil P., Ranveer, A. (2015), Sustainable Industrial Development, "International Journal for Research in Applied Science \& Engineering Technology (IJRASET)", 3 (XII), pp. 111-116. 


\section{Streszczenie}

\section{Postępy w osiągnięciu zrównoważonego rozwoju przemysłowego - przypadek Czech i Polski}

Celem artykułu jest wyjaśnienie koncepcji zrównoważonego rozwoju przemysłowego i przedstawienie wyników badania w zakresie postępów w osiąganiu celów w tej dziedzinie przyjętych przez Organizację Narodów Zjednoczonych (ONZ) w 2015 r. Analiza dotyczy czeskiej i polskiej gospodarki w okresie 2000-2018. Zgodnie z Agendą ONZ na rzecz Zrównoważonego Rozwoju 2030 zidentyfikowano także potrzebę promowania inkluzywnej i zrównoważonej industrializacji. W kontekście zrównoważonego rozwoju przemysłowego podkreśla się, że powinien on wspierać konkurencyjną gospodarkę, tworzyć miejsca pracy i chronić środowisko poprzez efektywne wykorzystanie zasobów nieodnawialnych. W celu oceny tego zjawiska w analizowanych gospodarkach wykorzystano wskaźniki zidentyfikowane przez ONZ w ramach SDG 9.

Słowa kluczowe: cele zrównoważonego rozwoju, SDG 9, zielona polityka przemysłowa, zrównoważony rozwój przemysłowy 